\title{
Society 5.0 and Social Development: Contributions to a Discussion
}

\author{
Carlos Miguel Ferreira ${ }^{1} \&$ Sandro Serpa ${ }^{2, *}$ \\ ${ }^{1}$ Interdisciplinary Centre of Social Sciences-CICS.NOVA, Polytechnic Institute of Castelo Branco, Estoril Higher \\ Institute for Tourism and Hotel Studies, 1069-061 Lisbon, Portugal \\ ${ }^{2}$ Department of Sociology, Faculty of Social and Human Sciences, University of the Azores, Interdisciplinary Centre \\ of Social Sciences-CICS.UAc/CICS.NOVA.UAc, and Interdisciplinary Centre for Childhood and \\ Adolescence-NICA—UAc, 9501-801 Ponta Delgada, Portugal \\ *Correspondence: Department of Sociology, Faculty of Social and Human Sciences, University of the Azores, \\ Interdisciplinary Centre of Social Sciences-CICS.UAc/CICS.NOVA.UAc, and Interdisciplinary Centre for \\ Childhood and Adolescence-NICA—UAc, 9501-801 Ponta Delgada, Portugal. E-mail: sandro.nf.serpa@uac.pt
}

Received: September 8, 2018

Accepted: September 23, 2018 Online Published: October 16, 2018

doi:10.5430/mos.v5n4p26

URL: https://doi.org/10.5430/mos.v5n4p26

\begin{abstract}
This opinion article intends to address the emergence of what will, potentially, be a central concept in a very near future, that of Society 5.0, and that emerges politically as a (con)sequence of the implementation of the concept of Industry 4.0. By proposing a deepening of the potential of the individual-technology relationship in fostering the improvement of the quality of life of all people through a super-intelligent society, Society 5.0 is an extremely recent concept as a guide for social development and that can have a profound impact on societies at all levels, such as in terms of the quality of life and sustainability. This presentation is based on very recent publications, but it also has a prospective component, which always generates some indeterminacy and uncertainty. Also for this reason, this contribution seeks, above all, to help in this very urgent and necessary discussion.
\end{abstract}

Keywords: society 5.0; industry 4.0; social development; sustainable innovation

\section{Introduction}

The idea of progress has been often associated with modernity and with the social theory itself (Mouzakitis, 2017; Chávarro, 2018; Salazar, 2016; Craipeau \& Metzger, 2007). In the bibliographical research carried out, as a curiosity, Wikipedia itself (English version, in a search made on April 14, 2018) refers to the concept of Industry 4.0 (Wikipedia, 2018a), which raises interest worldwide in several activity sectors (Ang, Goh, Saldivar, \& Li, 2017; Lin, Shyu, \& Ding, 2017; Reis \& Gins, 2017), but it does not (yet?) include the concept of Society 5.0 (Wikipedia, 2018b). According to Harayama (2017): "Society 5.0 is an information society built upon Society 4.0, aiming for a prosperous human-centered society” (p. 10).

This opinion article seeks to observe the emergence of what, potentially, will be a central concept in a very near future, that of Society 5.0 as "proposing to further the potential of the individual-technology relationship in fostering the enhancement of the quality of life of all people through a super smart society" (Serpa \& Ferreira, 2018, para. 1) and which emerges, in part, as a (con)sequence of the implementation of the concept of Industry 4.0. and its impact (Shamim, Cang, Yu, \& Li, 2017; Liao, Deschamps, Loures, \& Ramos, 2017; Compagna, Weidemann, Marquardt, \& Graf, 2016). This is an argumentative analysis, as a manuscript of positioning, which is based on a set of very recent publications, but which also has a prospective component, which always generates some indeterminacy. Also for this reason, this contribution seeks, above all, to collaborate in the opening of this discussion.

To this end, the next section presents and discusses the concept of Industry 4.0, followed by an analysis of the concept of Society 5.0. The article ends with a brief conclusion.

\section{Industry 4.0}

Industry 4.0 is very often regarded as somehow a fourth industrial revolution due to the profound effects it brings 
and will bring as a new productive paradigm with application in several activity areas (Abreu, 2018; Morrar, Arman, \& Mousa, 2017; Liu, Cao, Yang, \& Jiang, 2018; Shamim et al., 2017; Liao et al., 2017; Fraga-Lamas, Noceda-Davila, Fernández-Caramés, Díaz-Bouza, \& Vilar-Montesinos, 2016; Ang et al., 2017; Pilloni, 2018).

This concept of Industry 4.0 emerged in Germany in 2011, in the search to apply digital technologies to production (Abreu, 2018; Morrar et al., 2017; Pilloni, 2018; Ang et al., 2017; Hayashi, Sasajima, Takayanagi, \& Kanamaru, 2017).

The concept of Industry 4.0 is generally accepted in the body of scientific knowledge (Abreu, 2018), notwithstanding some variations in its definition and in the consideration of its social and political implications (Müller, Kiel, \& Voigt, 2018). But what does exactly Industry 4.0 consist of? It may be considered that it "consists of comprehensive and systematic digital networking of the creation, logistics and use of products or services" (Hennies \& Raudjärv, 2015, p. 1).

Industry 4.0 seeks an integration between technology, virtual space and the human being, between the real world and the virtual world, resulting in a true collaborative network (Hennies \& Raudjärv, 2015; Rubio-Tamayo, Gertrudix Barrio, \& García García, 2017) that articulates: intelligent robots; automated simulations; Internet of Things; cloud computing; additive manufacture; and big data analytics (Ang et al., 2017).

In this logic of integration of the real with the digital, the "smart factory" is central (Lin et al., 2017): "The smart factory is a core concept of Industry 4.0, which employs cyber-physical systems to monitor the physical production processes of the factory and make decentralized decision-making possible. Then the physical systems become the Internet of Things, communicating and cooperating both with each other and with humans in real-time via the wireless web” (p. 4).

According to Müller et al. (2018), Industry 4.0's attention is too focused on the economic and technological dimensions (Pfeiffer, 2016; Pilloni, 2018). Its social impact must also be taken into account, as well as, obviously, the technological impact (Morrar et al., 2017; Moniz \& Krings, 2016).

Innovation is another key concept in Industry 4.0 (Hennies \& Raudjärv, 2015; Palazzeschi, Bucci, \& Di Fabio, 2018; Shamim et al., 2017; Center for Research and Development Strategy: Japan Science and Technology Agency, 2017). In order for permanent innovation to occur, both individual and organisational learning for change and flexibility are essential, and learning for technology does not suffice (Abreu, 2018; Palazzeschi et al., 2018; Shamim et al., 2017; Morrar et al., 2017; Morrar et al., 2017).

This context, presented in a direct way, is one of the fundamental economic and social foundations of the emergence of Society 5.0.

\section{Society 5.0}

Wang, Yuan, Yong, Wang, Xiao, and Qin (2018) and Wang, Li, Yuan, Ye, and Wang (2016) indicate that the concept of Society 5.0 emerged in 2015 in Japan (Abreu, 2018), in a strategic national political initiative (Keidanren, 2016; Harayama, 2017; Center for Research and Development Strategy: Japan Science and Technology Agency, 2017). For Prasetyo and Arman (2017) and Costa (2018), Society 5.0 follows, to some extent, Industry 4.0, and, while Industry 4.0 focuses on production, Society 5.0 seeks to put humans at the centre of innovation. It also harnesses the impact of technology and results of Industry 4.0, with the deepening of technological integration in the improvement of the quality of life, social responsibility and sustainability (i-SCOOP, n/d, Serpanos, 2018).

According to Hayashi et al. (2017), with Society 5.0, Japan seeks

[...] [to] create new values by collaborating and cooperating with several different systems, and plans standardization of data formats, models, system architecture, etc. and development of necessary human resources. In addition, it is expected that enhancements of intellectual properties development, international standardization, IoT system construction technologies, big data analysis technologies, artificial intelligence technologies and so on encourage Japan's competitiveness in "super smart society" (p. 264).

Keidanren (Japan Business Federation) (2016) presents, as purposes of Society 5.0,

Every individual including elderly people and women can live safe and secured comfortable and healthy life and each and every individual can realize his/her desired lifestyle. [...] Improvement of productivity through digitization and reform of business models are promoted, and at the same time, the new economy and society will be realized by promoting innovation and globalization. [...] Efforts are made to solve a pile 
of issues of our country such as falling population, super aging society and natural disasters so that rich and vigorous future will be realized. Through overseas expansion of new businesses and services, we can contribute to solving global scale issues as well (p. 10).

There are several challenges to be faced, such as, for example, and according to Serpanos (2018), "software integration and upgrade, network interoperability, synchronization in light of real-time processes and applications, and, importantly, security" (p. 72). As maintained by Wang et al. (2018): "the fundamental theory of Societies 5.0 research is parallel intelligence, which is a novel methodology that extends the traditional artificial intelligence theories to the emerging cyber-physical-social systems (CPSS)" (p. 6).

To this end, the "Formulation of national strategies and integration of government promotion system", the "Development of laws toward implementation of advanced techniques", the "Formation of the knowledge foundation", the "Dynamic engagement of all citizens in the new economy and society", and the "Integration of advanced technologies and society" are critical (Keidanren (Japan Business Federation), 2016, p. 14).

Therefore, Society 5.0's ultimate purpose is to improve people's quality of life by mobilising the productive and technological potential of Industry 4.0 (Harayama, 2017). As an ultimate and, to some extent, unavoidable goal, Society 5.0 "promises to revolutionise society as we know it, and to improve our way of being and living in a community, in our personal and professional life" (Costa, 2018, para. 1).

According to the Center for Research and Development Strategy: Japan Science and Technology Agency (2017), with the progress and constant dynamics of Information Technology, individuals and societies will have enormous opportunities for innovation, growth and prosperity, on the basis of collaboration, co-creation and human-machine interaction. The Centre nevertheless draws attention to the fact that this development will entail ethical, legal and social challenges, as well as security and privacy ones, which must be safeguarded.

However, in order for this to be attained, it is necessary to anticipate a future in which

[...] people and the built and natural environments are melded at multiple temporal and spatial scales. The integration of sensing (embedded around, on, and in us), communication, and computation advances converging with our increased knowledge about human perception, cognition, behavior and physiological functions will likely create this future. Yet, to achieve this aspiring state, a fundamental conceptual rethinking is needed at different levels. First, rethinking of physical infrastructure not any longer considered only as a physical entity but deemed as a service; second reframing of other more traditional service systems as we know them today as cognitive cooperative systems. In this new realm the cyber-physical world will cooperate and work side by side with the human world. However, this future can only be viable with the emergence of new bold research to catalyze interdisciplinary social and hard sciences and engineering. These convergence is needed to shape human-technology partnerships that provide a sustainable, vibrant, livable people-centric world. Research, social and ethical implications of this future are discussed (Medina-Borja, 2017. p. 235).

The challenges posed to the implementation of Society 5.0. are therefore numerous.

\section{Conclusions}

Society 5.0 is a proposal for human and social development respecting sustainability, and a national design in Japan (Keidanren (Japan Business Federation), 2016). However, it is our understanding that this concept (or at least the underlying objectives) will be extended to other countries.

In order for the implementation of Society 5.0 not to be a sheer political-ideological concept, it seems that there is the need to integrate several dimensions, such as: "1) Innovation Policy (from government side), 2) Entrepreneurial spirit (from Society Side) and 3) Entrepreneurial Skills (from civil society and institutions)” (Yousefikhah, 2017, p. 38).

This is a topic with the future open, because, as I-SCOOP (n/d) maintains regarding a platform that provides publications, educational resources, training, practical consulting and services related to integrated marketing, digital business, transformation and organisational processes, "Whether such a vast societal change will work and the wall of social acceptance will be broken down is a question that will be answered in the future. Making predictions in this regard would be Western arrogance from our part and a big mistake. So: who knows? And is this a model we could envision in other parts of the world?” 


\section{Acknowledgments}

University of Azores, Interdisciplinary Centre of Social Sciences-CICS.UAc/CICS.NOVA.UAc, UID/SOC/04647/2013, with the financial support of FCT/MEC through national funds and when applicable co-financed by FEDER under the PT2020 Partnership Agreement.

Conflicts of Interest: The authors declare no conflict of interest.

\section{References}

Abreu, P. H. C. (2018). Perspectivas para a gestão do conhecimento no contexto da Indústria 4.0 [Perspectives for knowledge management in the context of Industry 4.0]. South American Development Society Journal, 4(10), 126. https://doi.org/10.24325/issn.2446-5763.v4i10p126-145

Ang, J., Goh, C., Saldivar, A., \& Li, Y. (2017). Energy-efficient through-life smart design, manufacturing and operation of ships in an Industry 4.0 environment. Energies, 10(5), 610. https://doi.org/10.3390/en10050610.

Center for Research and Development Strategy, Japan Science and Technology Agency (2017). Future Services \& Societal Systems in Society 5.0. Tokyo: Japan. Retrieved April 17, 2018 from https://www.jst.go.jp/crds/pdf/en/CRDS-FY2016-WR-13.pdf

Chávarro, L. A. (2018). Riesgo e incertidumbre como características de la sociedad actual: Ideas, percepciones y representaciones [Risk and uncertainty as characteristics of current society: Ideas, perceptions and representations]. Revista Reflexiones, 97(1), 65. https://doi.org/10.15517/rr.v97i1.31509.

Compagna, D., Weidemann, A., Marquardt, M., \& Graf, P. (2016). Sociological and biological insights on how to prevent the reduction in cognitive activity that stems from robots assuming workloads in human-robot cooperation. Societies, 6(4), 29. https://doi.org/10.3390/soc6040029.

Costa, J. M. (2018). Sociedade 5.0: A mudança que aí vem [Society 5.0: The change that is coming]. Retrieved April 13, 2018 from https://hrportugal.pt/sociedade-5-0-a-mudanca-que-ai-vem/

Craipeau, S., \& Metzger, J.-L. (2007). Pour une sociologie critique de la gestion [For a critical sociology of management]. Recherches Sociologiques et Anthropologiques, 38(1).

Fraga-Lamas, P., Noceda-Davila, D., Fernández-Caramés, T., Díaz-Bouza, M., \& Vilar-Montesinos, M. (2016). Smart pipe system for a shipyard 4.0. Sensors, 16(12), 2186. https://doi.org/10.3390/s16122186.

Harayama, Y. (2017). Society 5.0: Aiming for a new human-centered society. Collaborative creation through global R\&D open innovation for creating the future. Hitachi Review, 66(6), 8-13.

Hayashi, H., Sasajima, H., Takayanagi, Y., \& Kanamaru, H. (2017). International standardization for smarter society in the field of measurement, control and automation. Proceedings of the 56th Annual Conference of the Society of Instrument and Control Engineers of Japan (SICE). Kanazawa, Japan: Institute of Electrical and Electronics Engineers (IEEE). https://doi.org/10.23919/sice.2017.8105723.

Hennies, M., \& Raudjärv, M. (2015). Industry 4.0. Introductory thoughts on the current situation. Estonian Discussions on Economic Policy, 23(2). https://doi.org/10.15157/tpep.v23i2.12491.

i-SCOOP (n/d). From Industry 4.0 to Society 5.0: The big societal transformation plan of Japan. Retrieved April 13, 2018 from https://www.i-scoop.eu/industry-4-0-society-5-0/

Keidanren (Japan Business Federation) (2016). Toward realization of the new economy and society. Reform of the economy and society by the deepening of "Society 5.0". Retrieved April 16, 2018 from http://www.keidanren.or.jp/en/policy/2016/029_outline.pdf

Liao, Y., Deschamps, F., Loures, E. de F. R., \& Ramos, L. F. P. (2017). Past, present and future of Industry 4.0 - A systematic literature review and research agenda proposal. International Journal of Production Research, 55(12), 3609-3629. https://doi.org/10.1080/00207543.2017.1308576.

Lin, K., Shyu, J., \& Ding, K. (2017). A cross-strait comparison of innovation policy under Industry 4.0 and sustainability development transition. Sustainability, 9(5), 786. https://doi.org/10.3390/su9050786.

Liu, X., Cao, J., Yang, Y., \& Jiang, S. (2018). CPS-based smart warehouse for Industry 4.0: A survey of the 
underlying technologies. Computers [Internet]. $\quad$ MDPI $\quad A G, \quad 7(1), \quad 13$. http://dx.doi.org/10.3390/computers7010013.

Medina-Borja, A. (2017). Smart Human-Centered Service Systems of the Future. In Center for Research and Development Strategy, Japan Science and Technology Agency (2017), Future Services \& Societal Systems in Society 5.0 (pp. 235-239). Tokyo: Japan.

Moniz, A., \& Krings, B.-J. (2016). Robots working with humans or humans working with robots? Searching for social dimensions in new human-robot interaction in industry. Societies, 6(3), 23. https://doi.org/10.3390/soc6030023.

Morrar, R., Arman, H., \& Mousa, S. (2017). The fourth industrial revolution (Industry 4.0): A social innovation perspective. Technology Innovation Management Review, 7(11), 12-20. https://doi.org/10.22215/timreview/1117.

Mouzakitis, A. (2017). Modernity and the idea of progress. Frontiers in Sociology, 2. https://doi.org/10.3389/fsoc.2017.00003.

Müller, J. M., Kiel, D., \& Voigt, K.-I. (2018). What drives the implementation of industry 4.0? The role of opportunities and challenges in the context of sustainability. Sustainability, 10(1), 247. https://doi.org/10.3390/su10010247.

Palazzeschi, L., Bucci, O., \& Di Fabio, A. (2018). Re-thinking innovation in organizations in the industry 4.0 scenario: New challenges in a primary prevention perspective. Frontiers in Psychology, 9. https://doi.org/10.3389/fpsyg.2018.00030.

Pfeiffer, S. (2016). Robots, Industry 4.0 and humans, or why assembly work is more than routine work. Societies, 6(2), 16. https://doi.org/10.3390/soc6020016.

Pilloni, V. (2018). How data will transform industrial processes: Crowdsensing, crowdsourcing and big data as pillars of Industry 4.0. Future Internet, 10(3), 24. https://doi.org/10.3390/fi10030024.

Prasetyo, Y. A., \& Arman, A. A. (2017). Group management system design for supporting Society 5.0 in smart society platform. Proceedings of the 2017 International Conference on Information Technology Systems and Innovation (ICITSI). Bandung, Indonesia: IEEE. https://doi.org/10.1109/icitsi.2017.8267977.

Reis, M., \& Gins, G. (2017). Industrial process monitoring in the big data/Industry 4.0 era: From detection, to diagnosis, to prognosis. Processes, 5(4), 35. https://doi.org/10.3390/pr5030035.

Rubio-Tamayo, J., Gertrudix Barrio, M., \& García García, F. (2017). Immersive environments and virtual reality: Systematic review and advances in communication, interaction and simulation. Multimodal Technologies and Interaction, 1(4), 21. https://doi.org/10.3390/mti1040021.

Salazar, J. J. R. (2016). Un campo en construcción: Sociología de la Gerencia [A field under construction: Sociology of Management]. Cuaderno Venezolano de Sociología, 25(4), 143-157.

Serpa, S., \& Ferreira, C. M. (2018). Special Issue Society 5.0: Innovation, Uncertainty and Social Sciences. Retrieved August 18, 2018 from http://www.mdpi.com/journal/socsci/special_issues/Society_5.0

Serpanos, D. (2018). The cyber-physical systems revolution. Computer, 51(3), 70-73.

Shamim, S., Cang, S., Yu, H., \& Li, Y. (2017). Examining the feasibilities of Industry 4.0 for the hospitality sector with the lens of management practice. Energies, 10(4), 499. https://doi.org/10.3390/en10040499.

Yousefikhah, S. (2017). Sociology of innovation: Social construction of technology perspective. AD-Minister, 31-43. https://doi.org/10.17230/ad-minister.30.2.

Wang, X., Li, L., Yuan, Y., Ye, P., \& Wang, F.-Y. (2016). ACP-based social computing and parallel intelligence: Societies 5.0 and beyond. CAAI Transactions on Intelligence Technology, 1(4), 377-393. https://doi.org/10.1016/j.trit.2016.11.005.

Wang, F.-Y., Yuan, Y., Wang, X., \& Qin, R. (2018). Societies 5.0: A new paradigm for computational social systems research. IEEE Transactions on Computational Social Systems, 5(1), 1-8. https://doi.org/10.1109/TCSS.2018.2797598

Wikipedia (2018a). Industry 4.0. Retrieved April 14, 2018 from https://en.wikipedia.org/w/index.php?search=industry+4.0\&title=Special:Search\&profile=default\&fulltext=1\&s earchToken=6avaxwskzcbhhmgmrw5y80v52 
Wikipedia (2018b) Society 5.0. $\quad$ Retrieved $\quad$ April $\quad 14, \quad 2018 \quad$ from https://en.wikipedia.org/w/index.php?search=society+5.0\&title=Special\%3ASearch\&go=Go 